\title{
Evaluation of the Effect of the Incorporation of Blends of Fuel and Fluxing Wastes in Red Clay Ceramics
}

\author{
Gabriela Nunes Sales Barreto ${ }^{a}{ }^{\infty}$, Michelle Pereira Babisk ${ }^{a} \oplus$, Geovana Carla Girondi Delaqua ${ }^{a}$, \\ Monica Castoldi Borlini Gadiolib ${ }^{\circledR}$, Carlos Maurício Fontes Vieira ${ }^{a}{ }^{(0)}$ \\ ${ }^{a}$ Laboratório de Materiais Avançados (LAMAV), Universidade Estadual do Norte Fluminense (UENF), \\ Campos dos Goytacazes, RJ, Brasil \\ ${ }^{b}$ Centro de Tecnologia Mineral (CETEM/MCTIC), Núcleo Regional do Espírito Santo, Cachoeiro de \\ Itapemirim, ES, Brasil
}

Received: February 23, 2019; Revised: September 04, 2019; Accepted: October 16, 2019

\begin{abstract}
The clay samples endure the incorporation of industrial and urban wastes, which do not cause large variations in their properties if added in controlled quantities. Wastes can be classified as fuel, fluxing and property affecting wastes. The fuel wastes usually have a high amount of organic matter, that when heated cause exothermic reactions, releasing heat to the process. The fluxing wastes cause a reduction in the ceramic melting points. The main aim of this work was to study the behavior of ceramics incorporated with fuel wastes (Eichhornia crassipes dry biomass) and fluxing wastes (granite) as well as blends of both wastes. Different compositions were prepared with incorporation of different percentages of these wastes in the clay samples, conformed by uniaxial pressing and fired at 550, $650,750,850,950$ e $1050^{\circ} \mathrm{C}$. The technological properties tested were: dry apparent density, linear shrinkage, water absorption and flexural rupture strength. Results indicate that the high calorific value of the biomass waste represents a great possibility of saving energy for the firing process. Incorporations can be indicated as a possibility of correct destination for the investigated wastes.
\end{abstract}

Keywords: Red ceramics, fuel wastes, fluxing wastes, Eichhornia crassipes, granite.

\section{Introduction}

An increasing amount of all waste types is resulted by the human consumption habits combined with current industrial activities. The wastes are produced and when their final disposal is performed improperly, it can generate series of disorders like landscape, fauna and flora destruction, air and soil contamination bringing health risks to the population. One of the ways to minimize that impact is the waste reuse'.

Therefore, it is important to find practical and economic waste destinations. The incorporation of industrial and urban wastes in red ceramic matrices has been widely used nowadays, both as alternative raw materials and as an environmentally correct waste disposal. The masses used in ceramic industry are heterogenic by nature, resulting in the presence of residual materials from different types and sources, even in high percentagens ${ }^{2}$. Waste incorporation can be beneficial to the final product, since the waste may have chemical or mineralogical compositions of interest to the ceramic industrial process or they can provide heat of combustion which reduces the energy consumption during the firing stage ${ }^{3}$.

According to Vieira and Monteiro ${ }^{4}$, the different types of solid wastes that can be incorporated into red ceramics can be classified in three categories according to their nature and to the ceramic products properties.
- $\quad$ Fuel wastes - wastes that present high calorific value due to its high concentration of organic matter that contributes energetically to the ceramic sintering process through the energy release from the exothermic firing reactions.

- $\quad$ Fluxing wastes - wastes containing alkaline and earth alkaline compounds that in reaction with silica and alumina form liquid phases, increasing densification, reducing the melting point, helping to reduce the sintering temperatures.

- $\quad$ Property affecting wastes - wastes containing substances that modify ceramic behavior such as those that interfere in mechanical resistance, water absorption and linear shrinkage, but cannot be included in the first two categories ${ }^{4}$.

Several works study the effects of these different wastes such as stone, glass, red mud, biomass, different ashes and sludge incorporated into red ceramics separately ${ }^{5-13}$. However, few works mix two different waste types to analyze the effects of their incorporation blended. As fuel wastes tend to increase ceramic porosity after firing, its use combined with fluxing wastes may minimize this deleterious effect.

The objective of this work was to evaluate the effect of the incorporation of fuel (dry Eichhornia crassipes biomass) and fluxing (granite) wastes in the properties of clay ceramics 
fired at different temperatures, as well as incorporated with blends of the two waste types with different proportions.

\section{Materials and Methods}

Clay ceramic, dry macrophyte biomass and granite waste were the raw materials used in this work. The clay ceramic was collected at ArtCerâmica Sardinha, located in the city of Campos dos Goytacazes, Rio de Janeiro, Brazil, and it is constituted by 1:1 portions of "weak" and "strong" yellow clays. The Eichhornia crassipes biomass was collected at Lagoa do Vigário also located in Campos dos Goytacazes. The granite waste was collected in a sawmill in the city of Cachoeiro de Itapemirim, Espírito Santo, Brazil, from the filter press waste pile.

The clay ceramic is typical clay mass normally used by local ceramic industries in the production of bricks and tiles. Dry biomass waste is from Eichhornia crassipes (an aquatic macrophyte popularly known as aguapé), a common plant in local rivers and lagoons, most often introduced on purpose by man to purify water. However, the excess of this plant in water surface caused by its high reproduction rate presents damage to the ecosystem. Granite waste comes from granite industry, due to sawing and polishing process of granite rocks with diamond wire technology.

The clay ceramic was dried at $110^{\circ} \mathrm{C}$ for 24 hours, and then separated in a jaw crusher, disintegrated in a porcelain mortar and sieved to 42 mesh powder.

The biomass was washed in running water, dried in an air circulation stove and then in a laboratory stove at $60^{\circ} \mathrm{C}$. After dried, the material was ground in a knife mill and sieved through a 24 mesh sieve. The granite waste was dried at room temperature for excessive moisture loss and dried in a stove at $110^{\circ} \mathrm{C}$, then sieved at 42 meshes.

Waste characterization was made to evaluate their behaviors as fuel or fluxing wastes. Differential scanning calorimetric (DSC) and thermogravimetric (TG) analysis were performed to evaluate the thermal behavior and the nature of the reactions of the Eichhornia crassipes. The DSC/ TG analyses were done with a heating rate of $10^{\circ} \mathrm{C} / \mathrm{min}$ in a SDT Q600 V20.9 Build 2O. To evaluate its behavior as a fuel, heat combustion analysis was performed according to ASTM D5865-13 ${ }^{14}$.

$\mathrm{X}$-ray fluorescence (XRF) analysis was performed in the granite waste in AXIOS Paranalytical spectrometer to evaluate and quantify the presence of alkaline and earth alkaline compounds.

Particle size distribution of clay ceramic and granite waste were done by sifting and sedimentation process while particle size distribution of biomass was investigated by laser diffraction. Optical microscopy (OM) was performed onan OLYMPUS Microscope model LEXT OLS4000 3D.

Table 1 presents the five compositions formulated of clay ceramic samples incorporated with different percentages of wastes. The compositions were prepared with blend additions of different biomass and granite waste weight percentages in clay ceramic. Those specific percentages were chosen based on the literature review which showed that red ceramics incorporated with up to $5 \%$ w of biomass b $^{9,15}$ and up to $30 \% \mathrm{w}$ of granite $^{8}$ do not present depreciation in mechanical properties.

Table 1. Nomenclature and compositions (\%weight).

\begin{tabular}{lccc}
\hline Composition & $\begin{array}{c}\text { Clay Ceramic } \\
(\%)\end{array}$ & $\begin{array}{c}\text { DryBiomass } \\
(\%)\end{array}$ & $\begin{array}{c}\text { Granite } \\
\text { Waste }(\%)\end{array}$ \\
\hline 0 & 100 & 0 & 0 \\
$2.5 \mathrm{~B} 20 \mathrm{G}$ & 77.5 & 2.5 & 20 \\
$2.5 \mathrm{~B} 30 \mathrm{G}$ & 67.5 & 2.5 & 30 \\
$5 \mathrm{~B} 20 \mathrm{G}$ & 75 & 5 & 20 \\
$5 \mathrm{~B} 30 \mathrm{G}$ & 65 & 5 & 30 \\
\hline
\end{tabular}

The samples of the five compositions prepared were wetted with $8 \%$ water and conformed by uniaxial pressing in a hydraulic press in $15 \mathrm{MPa}$, set in a rectangular steel mold $(114$ X $25 \mathrm{~mm})$. The samples were dried at room temperature and in a laboratory stove at $110^{\circ} \mathrm{C}$ for 24 hours, then fired at $550,650,750,850,950$ and $1050^{\circ} \mathrm{C}$ in a laboratory oven. The heating rate used was $3^{\circ} \mathrm{C} / \mathrm{min}$ maintaining the maximum temperature for an hour in each firing temperature mentioned before and with a natural convection cooling after shutting off the oven.

In order to verify the mobility of pollutants leaching and solubilizations tests, according to NBR $10005^{16} \mathrm{e}$ NBR $10006^{17}$, were performed in granite and biomass. The elements, as well as other substances required by the NBR $10004^{18}$ standard were determined in the solubilization and leaching extracts.

In order to evaluate the mechanical properties, the dry apparent density, linear shrinkage and water absorption tests were done according to ASTM C373-72 ${ }^{19}$ and the three-point flexural rupture strength based on the ASTM C674-77 ${ }^{20}$.

\section{Results and Discussion}

Figure 1 shows the DSC and TG biomass analysis, performed to investigate its thermal behavior.

In Figure 1 it is noticed that around $100^{\circ} \mathrm{C}$ there is an endothermic peak that characterizes biomass loss of adsorbed water, associated with an average mass loss. Twowell-defined exothermic peaks between \pm 280 e $525^{\circ} \mathrm{C}$, associated with a $\pm 55 \%$ mass loss which shows that the biomass releases heat in this temperature range assisting sintering process of clay ceramics through heat releasing as well as energy savings during the firing process.

Table 2 shows the chemical composition of the granite waste, which is similar to one of the clays used to prepared the red ceramics. 


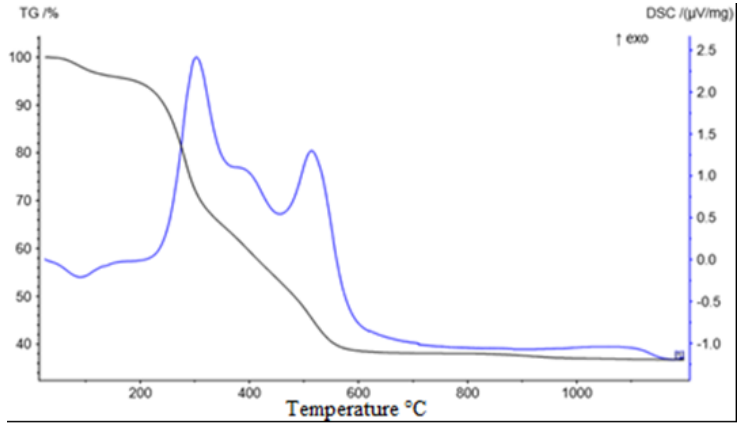

Figure 1. DSC/TG Eichhornia crassipes dry biomass curves.

It is possible to observe the presence of $\mathrm{SiO}_{2}(69.9 \%)$ followed by $\mathrm{Al}_{2} \mathrm{O}_{3}(17 \%)$ and a significant amount of alkaline oxides $\left(\mathrm{K}_{2} \mathrm{O}\right.$ and $\left.\mathrm{Na}_{2} \mathrm{O}\right)$, in a total of $8.9 \%$, in contrast with the local clays collected in Campos dos Goytacazes/RJ (Brazil), that naturally have a low flux content ${ }^{8}$ as a consequence of being kaolinitic clays ${ }^{21}$. The alkaline oxides may act as fluxes, improving the sintering process by reacting with silica and alumina to form liquid phase by eutectic reaction ${ }^{8}$.

Another advantage of the granite waste is its low content of $1.3 \% \mathrm{Fe}_{2} \mathrm{O}_{3}$, when compared to the clays collected in Rio de Janeiro/RJ (Brazil) ${ }^{22}$. The absence of iron compounds in the clay masses not only avoids damage to the wear of processing equipment, but also ceramic clays with a content below $3 \% \mathrm{Fe}_{2} \mathrm{O}_{3}$ are indicated for the manufacture of lightcolored products.

One final comment on the results of Table 2 is that the granite waste low fire loss (LoI) of $0.55 \%$ indicates thermal stability. Excessive LoI can cause more retraction and porosity after firing.

Figure 2 shows the particle size distribution curves of raw materials. In this figure, the different particle size range is associated with the clay, silt and sand classification ${ }^{23}$. The clay fraction is associated to particle sizes smaller than $0,002 \mathrm{~mm}$, the silt fraction between 0,002 e $0,02 \mathrm{~mm}$ and the sand fraction particles bigger than $0,02 \mathrm{~mm}$. The clay fraction provides the clay samples greater plasticity since in its range of particle size, there is a higher percentage of clay minerals. The sand fraction represents coarser particles being associated with quartz and responsible for the adjustment of workability, reduction of plasticity and linear shrinkage ${ }^{23}$.

Table 3 shows the particle size distribution of raw materials. Granite waste presents granulometry distributed in $85.6 \%$ of silt, $11.9 \%$ of clay and only $2.5 \%$ of sand. Biomass presents granulometry distributed in $83.3 \%$ of sand, $15.6 \%$ of silt and only $0.6 \%$ of clay. Both presented coarser granulometry than the clay ceramic ( $43 \%$ of clay, $42 \%$ of silt and $15 \%$ of sand).

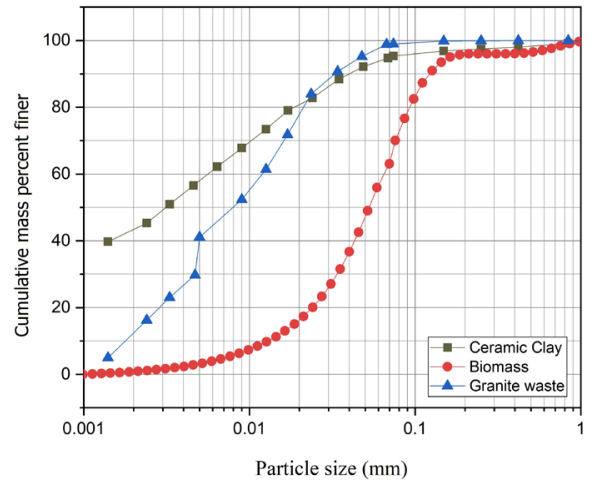

Figure 2. Particle size distribution of raw materials.

Despite of the wastes presenting a coarser granulometry than the clay, they have enough fine granulometry to be used in the formulation of the clay body.

Figure 3 shows the images of raw materials obtained by optical microscopy.
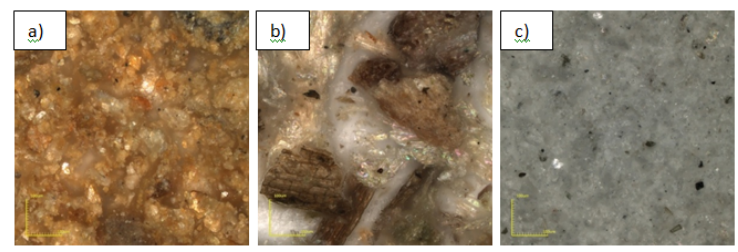

Figure 3. Images by Optical microscopy a) ceramic clay b) biomass c) granite waste $(430 \mathrm{x})$.

In Figure $3 \mathrm{a}$ it can be noticed different size particles andalso it's possible to observe quartz particles, as well as dark and red particles associated with iron compounds. In Figure $3 \mathrm{~b}$ diversified size particles can be observed, mostly large, with irregular shape. In Figure 3 cit is possible to analyze a large number of agglomerates and thin particles and it is possible to observe dark and red particles associated with minerals founded in the granite waste, such as biotite and ferromaginetic minerals ${ }^{24}$.

When comparing the leaching results for metals are presented in Table 4 with the maximum values allowed by NBR 10004 - Annex $\mathrm{F}^{18}$, it is verified that the obtained parameters did not exceed allowed limits, thus, granite waste and Eichhornia crassipes dry biomass do not present toxicity. Therefore, in relation to the analyzed metals both are classified as being Class II, non-hazardous wastes.

The results of the solubilization test of the wastes are presented in Table 5 and comparing those results with the maximum values allowed by NBR 10004 - Annex G $^{18}$ it

Table 2. Chemical composition of granite waste (wt.\%).

\begin{tabular}{ccccccccccc}
\hline Components & $\mathrm{SiO}_{2}$ & $\mathrm{CaO}$ & $\mathrm{K}_{2} \mathrm{O}$ & $\mathrm{Na}_{2} \mathrm{O}$ & $\mathrm{Al}_{2} \mathrm{O}_{3}$ & $\mathrm{Fe}_{2} \mathrm{O}_{3}$ & $\mathrm{MgO}$ & $\mathrm{P}_{2} \mathrm{O}_{5}$ & $\mathrm{TiO}_{2}$ & Lol \\
\hline & 69.9 & 1.5 & 3.4 & 5.5 & 17 & 1.3 & 0.46 & 0.14 & 0.24 & 0.55 \\
\hline
\end{tabular}


Table 3. Particle size distribution of raw materials (\%).

Particle Size Distribution of Raw Materials (\%)

\begin{tabular}{lccc} 
& Clay Fraction & Silt Fraction & Sand Fraction \\
\hline Clay ceramic & 43 & 42 & 15 \\
Biomass & 0.6 & 15.6 & 83.3 \\
Granite waste & 11.9 & 85.6 & 2.5 \\
\hline
\end{tabular}

Table 4. Analytical results of the leaching extract.

\begin{tabular}{lccccc}
\hline Parameters & $\begin{array}{c}\text { NBR 10004:2004 } \\
(\mathrm{mg} / \mathrm{L})\end{array}$ & $\begin{array}{c}\text { Granite waste } \\
(\mathrm{mg} / \mathrm{L})\end{array}$ & Results & Biomass $(\mathrm{mg} / \mathrm{L})$ & Results \\
\hline Arsenic & 1 & 0.02 & Inside the limit & 0.03 & Inside the limit \\
Barium & 70 & 0.73 & Inside the limit & 0.48 & Inside the limit \\
Cadmium & 0.5 & $<0.0004$ & Inside the limit & $<0.0002$ & Inside the limit \\
Lead & 1 & 0.03 & Inside the limit & $<0,008$ & Inside the limit \\
Total chrome & 5 & $<0.001$ & Inside the limit & 0.01 & Inside the limit \\
Mercury & 0.1 & $<0.009$ & Inside the limit & 0.05 & Inside the limit \\
Silver & 5.0 & $<0.005$ & Inside the limit & $<0.005$ & Inside the limit \\
Selenium & 1 & $<0.008$ & Inside the limit & 0.05 & Inside the limit \\
\hline
\end{tabular}

is verified that for granite waste, the parameter aluminum above the maximum limit allowed. Regarding the biomass, the parameters iron, manganese, mercury and sodium are above the maximum limits allowed. Thus, the both wastes are classified as Class II A - non-inert in relation to the metals analyzed. These metals come from the Eichhornia crassipes phytoremediation assimilation, which is a characteristic of this plant, to absorb chemical elements from the environment in which they developed ${ }^{25}$. The Vigario Lagoon, where the plants were collected to prepare dry biomass for this research is polluted due to the dischards of domestic and industrial effluents and garbage ${ }^{26}$.

Figure 4 shows the clay samples' location with different percentages of blend in an extrusion prognostic diagram based on the Atteberg limits.

As shown in Figure 4, the ceramic clay is outside the region of acceptable plasticity for extrusion. The addition of blend compositions to the clay samples provides an acceptable extrusion workability.

Figure 5 shows the dry apparent density of the 5 studied compositions.

The denser the ceramic samples, the better "packaged" it is, because its grains are closer and there are less empty spaces between then. It is beneficial in the ceramic industry because the increase of particles contact area helps sintering. However, the increase in the densification causes a decrease in the ceramic sample's permeability, which can impair the drying and the organic matter elimination during firing cycle. Statistically, it can be observed that the granite and biomass waste incorporation did not change the dry apparent density when comparing to the pure ceramic clay.

Figure 6 shows the linear shrinkage of all fired compositions.
In Figure 6 it can be observed that the linear shrinkage increases according to the increase of firing temperature. This is due to more efficient sintering at higher temperatures, which results in a larger pore closure and reduction of the bodies'dimensions ${ }^{22}$.

From Figure 6 it is also noticed that the linear shrinkage tends to have a small decrease with blend incorporation, and this decrease is more pronounced in those compositions that contain the highest amount of granite waste. At $1050^{\circ} \mathrm{C}$ there was an increase in linear shrinkage for all compositions due to its higher liquid phase formation, because of the granite fluxing action, as discussed above.

Figure 7 shows the percentage water absorption of the compositions.

In Figure 7 it is possible to notice that at $1050^{\circ} \mathrm{C}$, water absorption decreases which is due to more effective sintering at higher temperatures, resulting in a greater closure of open pores, thus reducing water absorption. The lower water infiltration in the ceramic body determines, for example, the grater durability and resistance to the environment to which the material is exposed.

It should be noted that the compositions with the lowest amounts of biomass cause a decrease in the water absorption and the ones with the highest amounts of biomass caused an increase. At $1050^{\circ} \mathrm{C}$ all blend compositions caused a decrease in water absorption. The smaller the amount of biomass waste and the greater the amount of granite waste, the greater the water absorption reduction was, due to the liquid phase formation by the present fluxing oxides.

These results are explained by the combustion of the biomass organic matter during the firing stage, associated with a mass loss that causes ceramic porosity, a natural behavior 
Table 5. Analytical results of the solubilization extract.

\begin{tabular}{|c|c|c|c|c|c|}
\hline Parameters & $\begin{array}{c}\text { NBR 10004:2004 } \\
(\mathrm{mg} / \mathrm{L})\end{array}$ & $\begin{array}{l}\text { Granite waste } \\
\text { (mg/L) }\end{array}$ & Results & Biomass (mg/L) & Results \\
\hline Aluminium & 0.2 & 3.85 & Out of limit & $<0.007$ & Inside the limit \\
\hline Arsenic & 0.01 & $<0.008$ & Inside the limit & $<0.008$ & Inside the limit \\
\hline Barium & 0.7 & 0.26 & Inside the limit & 0.29 & Inside the limit \\
\hline Cadmium & 0.005 & $<0.0004$ & Inside the limit & $<0.0002$ & Inside the limit \\
\hline Lead & 0.01 & $<0.008$ & Inside the limit & $<0.008$ & Inside the limit \\
\hline Copper & 2 & $<0.01$ & Inside the limit & $<0,0003$ & Inside the limit \\
\hline Total chromium & 0.05 & $<0.001$ & Inside the limit & $<0.001$ & Inside the limit \\
\hline Iron & 0.3 & 0.19 & Inside the limit & 0.35 & Out of limit \\
\hline Manganese & 0.1 & 0.06 & Inside the limit & 14.7 & Out of limit \\
\hline Mercury & 0.001 & $<0.009$ & Inside the limit & 0.065 & Out of limit \\
\hline Silver & 0.05 & $<0.005$ & Inside the limit & $<0.005$ & Inside the limit \\
\hline Selenium & 0.01 & $<0.008$ & Inside the limit & 0.055 & Out of limit \\
\hline Sodium & 200 & 19 & Inside the limit & 226 & Out of limit \\
\hline Zinc & 5 & 0.065 & Inside the limit & 0.77 & Inside the limit \\
\hline
\end{tabular}

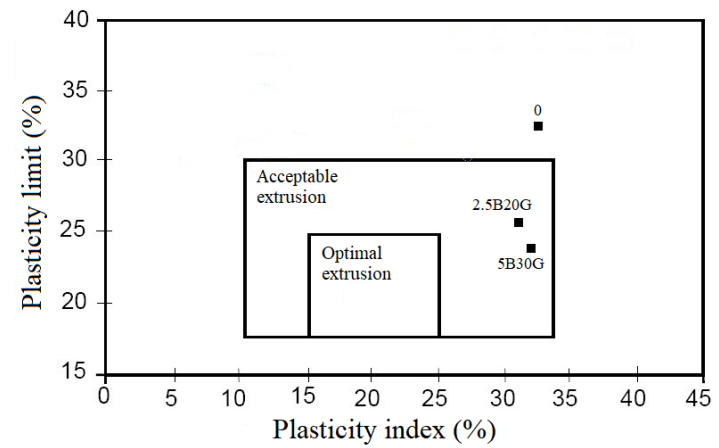

Figure 4. Extrusion prognostics.

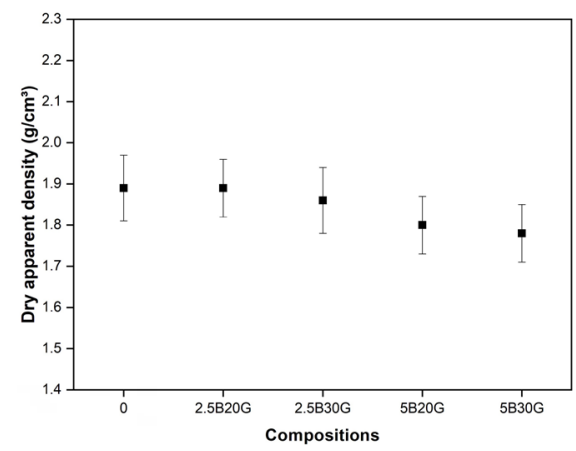

Figure 5. Dry apparent density of compositions.

of this type of residue, as evidenced by thermal analysis. Meanwhile, at $1050^{\circ} \mathrm{C}$ the formation of liquid phase helps to fill these pores and the water absorption values decrease.

For structural clay bricks, according to NBR ISO 15270:1 (2017), the water absorption index must not be less than $8 \%$

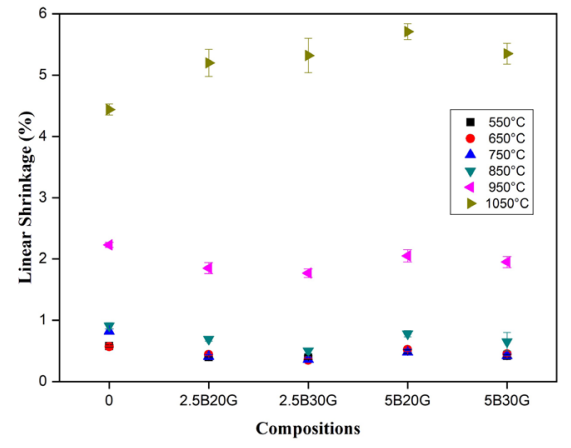

Figure 6. Linear shrinkage of compositions.

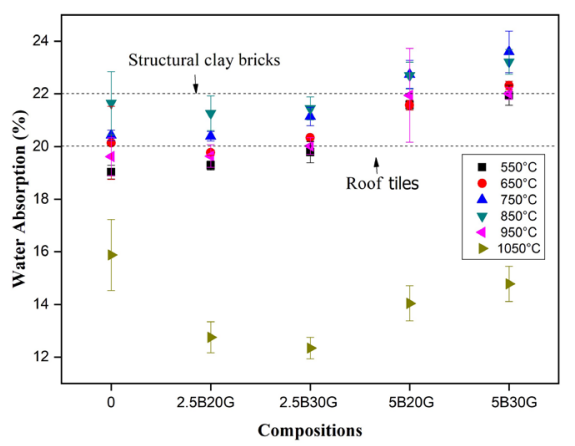

Figure 7. Water absorption of compositions.

or more than $25 \%{ }^{27}$. The results obtained for all studied compositions meet the normative limits for structural clay bricks. NBR ISO 15310 (2009) indicates that the maximum permissible limit of water absorption for ceramic roof tiles is $20 \%^{28}$. All compositions burned at $1050^{\circ} \mathrm{C}$ and also 
compositions with $2.5 \%$ of biomass burned at 550, 950 and $1050^{\circ} \mathrm{C}$ are suitable for roof tiles manufacture.

Figure 8 shows flexural rupture strength of the compositions.

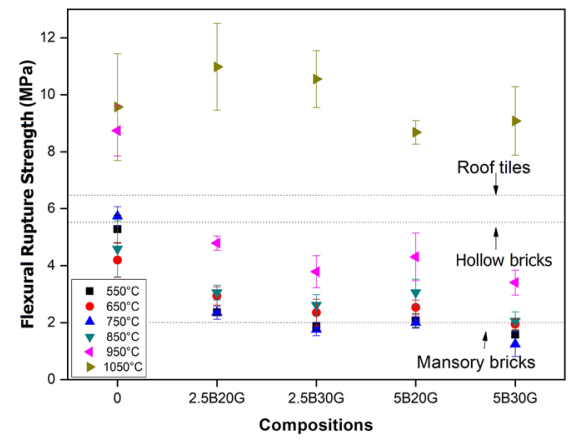

Figure 8. Flexural rupture strength of compositions.

The flexural strength, or stress at which the material breaks, is the most important property for structural material and this property increases with the temperature increase, mainly to $1050^{\circ} \mathrm{C}$. As previously discussed, this is due to the sintering mechanisms that allow greater formation of liquid phase, thus reducing the porosity of the material and promoting a better consolidation of the particles.

In Figure 8 it is noticed that the blend incorporation causes a decrease in the flexural rupture strength, except for the ones burned at $1050^{\circ} \mathrm{C}$, in which the compositions with the smaller biomass amount $(2.5 \%)$ cause an increase.

The minimum resistance required for the masonry bricks manufacture is $2 \mathrm{MPa}$, for hollow bricks is $5.5 \mathrm{MPa}$ and for roof tiles is $6.5 \mathrm{MPa}^{23}$. The results obtained at $1050^{\circ} \mathrm{C}$ for all compositions are above the minimum strength for manufacturing of these three products. Composition with highest amounts of granite, $2.5 \mathrm{~B} 30 \mathrm{G}$ and $5 \mathrm{~B} 30 \mathrm{G}$, are above the minimum strength for masonry bricks when fired at 550 and $750^{\circ} \mathrm{C}$.

The heat of combustion of a fuel material is divided into upper and lower heat of combustion and it is expressed by the energy content that is released from the materials when it is fired with air atmosphere. The higher heat of combustion is the parameter of interest for this research, and it refers to the amount of calories released by the material in its combustion. The higher this the high heat of combustion is, the bigger the energy contained in the fuel ${ }^{29}$. The heat of combustion obtained for the dry biomass of Eichhornia crassipes was $2.389 \mathrm{kcal} / \mathrm{kg}$.

For economic and energy analysis, data on the energy savings provided by the incorporation of $2.5 \% \mathrm{w}$ biomass in the ceramic mass will be provided. The energy saving survey was carried out for the firewood burning vaulted oven considering $900^{\circ} \mathrm{C}$ threshold temperature.
Data:

$\checkmark$ Firewood heat of combustion: $2.600 \mathrm{kcal} / \mathrm{kg}$.

$\checkmark$ Eichhornia crassipes biomass heat of combustion: $2.389 \mathrm{kcal} / \mathrm{kg}$.

$\checkmark$ Oven consumption of vaulted oven: $780.000 \mathrm{kcal} / \mathrm{T}$.

To produce 1 ton of the final product using firewood as fuel, the vault oven spends, on average: (oven consumption $(\mathrm{kcal} /$ ton $) /$ firewood heat of combustion $(\mathrm{kcal} / \mathrm{kg}))=$ $780.000 / 2.600=300 \mathrm{~kg}$ of firewood.

With the incorporation of $2.5 \%$ biomass waste, there is a reduction in the oven energy consumption reduction of: (amount of waste $(\mathrm{kg})) \mathrm{x}$ (biomass heat of combustion (kcal/ $\mathrm{kg})=25 \times 2.389=59.725 \mathrm{kcal}$.

With this data it is possible to calculate the percentage of energy saved during the firing, which will be: (calories provided by biomass $) /($ oven consumption $)=59.725 / 780.000$ $=7.7 \%$.

However, the theoretical heat required for firing $1 \mathrm{~kg}$ of ceramic clay is $256 \mathrm{kcal}$. This shows that the efficiency of the vault oven is about $30 \%$.

Considering that all the heat generated by the waste would be used, the firewood economy would be: firewood calories needed to provide the same energy from biomass $=100 \times 59.725 / 30=199.083 \mathrm{kcal}$

This is the energy saved with the incorporation of $2.5 \%$ biomass in ceramic clay and corresponds to a real reduction of $25 \%$ of the energy from the firewood $(59.725 / 780.000)$.

\section{Conclusions}

Regarding the objectives of this work, it can be noticed that the Eichhornia crassipes biomass waste and granite waste have suitable characteristics to be used as raw materials in the ceramic industry. The characterization results, as well as their influences in ceramic properties showed that they behaved as fuel and fluxing wastes, respectively, as proposed.

Both wastes were classified as non-hazard - Class II A (non-inert) according to NBR 10004.

Thus, it is evident the direct influence of both wastes and their blends in the technological ceramic properties evaluated:

- Blend compositions did not cause significant changes in the ceramic dry apparent density.

- With the blend incorporation, linear shrinkage presented a decrease for ceramic samples burned at all tested temperatures, except $1050^{\circ} \mathrm{C}$, which presented an increase.

- Compositions with lower amount of biomass presented a decrease in the water absorption while the ones with the higher amounts of biomass cause an increase of that.

- $\quad$ Flexural rupture strength decreases with blend incorporations, except for the ones fired at $1050^{\circ} \mathrm{C}$, 
in which the compositions with the smaller biomass amount $(2.5 \%)$ caused an increase of the property.

The heat of combustion of Eichhornia crassipes biomass is high, releasing heat during the firing process generating energy saving and a shorter firing time. The incorporation of $2.5 \% \mathrm{w}$ biomass in mass reduces around $25 \%$ of energy from the firewood (commonly used fuel).

In addition to the improvements of some ceramic mechanical properties, the use of these wastes and their blends allows the recycling of a material that could be unduly disposed, causing environmental damage.

\section{Acknowledgements}

The paper's authors acknowledge the aid provided form the Foundation for protection of Research and Innovation in Espírito Santo (FAPES) [grant number 80857019], the Coordination of improvement of higher education personnel (CAPES) [grant program code PNPD20131134 - 31033016005P8 UENF/Materials Engineering], the Rio de Janeiro State Research Support Foundation (FAPERJ) [grant number E-26/202.773/2017] and the Science and the Brazilian National Council for Scientific and Technological Development (CNPq) [grant number 301634/2018.1].

\section{References}

1. Saidelles APF, Senna AJT, Kirchner R, Bitencourt G. Gestão de resíduos sólidos na indústria de beneficiamento de arroz. Revista Eletrônica em Gestão, Educação e Tecnologia Ambiental REGET/UFSM. 2012;5(5):904-916.

2. Vieira CMF, Sanchez R, Monteiro SN, Lallá N, Quaranta N. Recycling of eletric arc furnace dust into red ceramics. Journal of Materials Research and Technology. 2013;2(2):88-92.

3. Abreu MM. Reciclagem de lama de alto forno em cerâmica vermelha [dissertation]. Campos dos Goytacazes (RJ): Universidade Estadual do Norte Fluminense Darcy Ribeiro (UENF); 2013.

4. Vieira CMF, Monteiro SN. Incorporation of solid wastes in red ceramics - an updated review. Revista Matéria. 2009;14(3):881-905.

5. Ribeiro LS, Babisk MP, Prado US, Monteiro SN, Vieira CMF. Incorporation of in natura and calcined red muds into clay ceramic. Materials Research. 2015;18(Suppl 2):279-282.

6. Aguiar MC, Gadioli MCB, Babisk MP, Candido VS, Monteiro $\mathrm{SN}$, Vieira CMF. Clay ceramic incorporated with granite waste obtained from diamond multi-wire sawing technology. Materials Science Forum. 2014;775-776:648-652.

7. Babisk MP, Ribeiro WS, Aguiar MC, Monteiro SN, Vieira CMF, Vidal FWH. Characterization of a Quartzite Residue and its Application in Red Clay Ceramics. Materials Science Forum. 2015;805:541-546.

8. Amaral LF, Carvalho JPRG, Silva BM, Delaqua GCG, Monteiro SN, Vieira CMF. Development of ceramic paver with ornamental rock waste. Journal of Materials Research and Technology. 2019;8(1):599-608.

9. Delaqua GCG, Vieira CMF, Amaral LF, Monteiro SN. Incorporation of Dry Biomass of Salviniaa uriculata aubl. The Process Of Phytoremediation in Ceramic Production. In: $60^{\circ}$ Congresso Brasileiro de Cerâmica; 2016 mai. 15-18; Águas de Lindóia (SP), Brasil. Águas de Lindóia (SP): $60^{\circ}$ Congresso Brasileiro de Cerâmica; 2016. p. 491-490.

10. Morais ASC, Vieira CMF, Rodriguez RJS, Monteiro SN, Candido VS, Ferreira CL. Fluorescent lamp glass waste incorporation into clay ceramic: a perfect solution. Journal of Economic Structures. 2016;68(9):2225-434.

11. Babisk MP, Altoé TP, Lopes HJO, Prado US, Gadioli MCB, Monteiro SN, Vieira CMF. Properties of clay ceramic incorporated with red mud. Materials Science Forum. 2014;798-799:509-513.

12. Babisk MP, Oliveira CN, Soares Júnior MP, Vieira CMF, Monteiro SN, Alexandre J. Effect of banana fiber in the properties of clayey ceramic. Materials Science Forum (Online). 2014;798-799:229-234.

13. Coutinho NC, Vieira CMF. Characterization and incorporation of MSWI ash in red ceramic. Cerâmica. 2016;62(363):249-255.

14. ASTM - American Society for Testing and Materials. D586513 - Standard Test Method for Gross Calorific Value of Coal and Coke. West Conshohocken, USA: ASTM; 2013.

15. Babisk MP, Barreto GNS, Delaqua GCG, Gadioli MCB, Vieira CMF. Incorporation of Eichhornia crassipes dry biomass in red ceramics. In: $73^{\circ}$ Congresso Annual da ABM; 2018 out. 2-4; São Paulo (SP), Brasil. São Paulo (SP): ABM; 2018. p. 1840-1850.

16. ABNT - Brazilian Standards Association. ABNT NBR $10005-$ Procedure for obtaining solubilized solid waste extract. Rio de Janeiro (RJ): ABNT; 2004. p. 1-16

17. ABNT - Brazilian Standards Association. ABNT NBR 10006 - Procedure for obtention of solubilized extraction of solid wastes. Rio de Janeiro (RJ): ABNT; 2004. p. 1-3.

18. ABNT - Brazilian Standards Association. ABNT NBR 10004 - Solid waste - Classification. Rio de Janeiro (RJ): ABNT; 2004. p. 1-71.

19. ASTM - American Society for Testing and Materials. C37372 - Water Absorption, Bulk Density, Apparent Porosity and Apparent Specific Gravity of Fired Whiteware Products. West Conshohocken, USA: ASTM; 1972.

20. ASTM - American Society for Testing and Materials. C67477 - Flexural Properties of Ceramic Whiteware Materials. West Conshohocken, USA: ASTM; 1977.

21. Monteiro SN, Vieira CMF. Influence of firing temperature on the ceramic properties of clays from Campos dos Goytacazes, Brazil. Applied Clay Science. 2004;27(3-4):229-234.

22. Babisk MP, Ribeiro AP, Monteiro SN, Vieira CMF. Development of ceramics based on clays from different regions in the state of Rio de Janeiro, Brazil. Materials Science Forum. 2015;805:530-535.

23. Santos PS. Science and Technology of Clays. $2^{\mathrm{a}}$ ed. São Paulo (SP): Edgard Blücher; 1989. 
24. Aguiar MC. Utilização de resíduo de serragem de rocha ornamental com tecnologia de fio diamantado em cerâmica vermelha [dissertation]. Campos dos Goytacazes: State University of Northern Rio de Janeiro; 2012.

25. Baker AJM. Accumulator sand excluder strategies in the response of plants to heavy metals. Journal of Plant Nutrition. 1981;3(1-4):643-654.

26. Souza FP. Estudo de ocupação espontânea na Lagoa do Vigário, no município de Campos dos Goytacazes - RJ, propostas mitigadores e amparo legal [dissertation]. Campos dos Goytacazes (RJ): Instituto Federal de Educação, Ciência e Tecnologia Fluminense; 2009.
27. ABNT - Brazilian Standards Association. ABNT NBR 15270-1Ceramic components - Clay bocks and bricks for masonry. Part 1: Requirements. Rio de Janeiro (RJ): ABNT; 2017. p. 1-26.

28. ABNT - Brazilian Standards Association (2009). NBR ISO 15310 - Ceramic components - Ceramic roof tiles - Terminology, requirements and testing methods. Rio de Janeiro (RJ): ABNT; 2009. p. 1-42.

29. Carvalho Júnior RM. Desenvolvimento e análise energética do processo de obtenção do biodiesel de microalga por metanólise in situ [dissertation]. Curitiba (PR): Universidade Federal do Paraná; 2010. 